\title{
Article \\ Discrimination of the Essential Oils Obtained from Four Apiaceae Species Using Multivariate Analysis Based on the Chemical Compositions and Their Biological Activity
}

\author{
Dilafruz N. Jamalova ${ }^{1,+}{ }^{+}$, Haidy A. Gad ${ }^{2,3,+}$ (D, Davlat K. Akramov ${ }^{4}$, Komiljon S. Tojibaev ${ }^{1}$, Nawal M. \\ Al Musayeib ${ }^{5}$, Mohamed L. Ashour ${ }^{2, *}$ (i) and Nilufar Z. Mamadalieva ${ }^{4, *(1)}$ \\ 1 Institute of Botany of the Academy Sciences of Uzbekistan, Durmon Yuli Str. 32, Tashkent 100125, Uzbekistan; \\ dilafruz.jamalova.91@mail.ru (D.N.J.); ktojibaev@mail.ru (K.S.T.) \\ 2 Department of Pharmacognosy, Faculty of Pharmacy, Ain Shams University, Cairo 11566, Egypt; \\ haidygad@pharma.asu.edu.eg \\ 3 Department of Pharmacognosy, Faculty of Pharmacy, King Salman International University, \\ South Sinai 46612, Egypt \\ 4 Institute of the Chemistry of Plant Substances, Academy of Sciences of RUz, Mirzo Ulugbek Str. 77, \\ Tashkent 100170, Uzbekistan; a.davlat@inbox.ru \\ 5 Department of Pharmacognosy, College of Pharmacy, King Saud University, Riyadh 11495, Saudi Arabia; \\ nalmusayeib@ksu.edu.sa \\ * Correspondence: ashour@pharma.asu.edu.eg (M.L.A.); nmamadalieva@yahoo.com (N.Z.M.); \\ Tel.: +20-10-68-222-354 (M.L.A.); +998-91-359-1676 (N.Z.M.); \\ Fax: +20-22-405-1107 (M.L.A.); +998-71-262-7348 (N.Z.M.) \\ check for \\ Citation: Jamalova, D.N.; Gad, H.A.; \\ + These authors contributed equally to this work.
} Akramov, D.K.; Tojibaev, K.S.; Musayeib, N.M.A.; Ashour, M.L.; Mamadalieva, N.Z. Discrimination of the Essential Oils Obtained from Four Apiaceae Species Using Multivariate Analysis Based on the Chemical Compositions and Their Biological Activity. Plants 2021, 10, 1529. https://doi.org/10.3390/plants10081529

Academic Editor: Salvatore

Antonino Raccuia

Received: 28 June 2021

Accepted: 22 July 2021

Published: 26 July 2021

Publisher's Note: MDPI stays neutral with regard to jurisdictional claims in published maps and institutional affiliations.

Copyright: (c) 2021 by the authors. Licensee MDPI, Basel, Switzerland. This article is an open access article distributed under the terms and conditions of the Creative Commons Attribution (CC BY) license (https:// creativecommons.org/licenses/by/ $4.0 /)$.

\begin{abstract}
The chemical composition of the essential oils obtained from the aerial parts of four Apiaceae species, namely Elaeosticta allioides (EA), E. polycarpa (EP), Ferula clematidifolia (FC), and Hyalolaena intermedia (HI), were determined using gas chromatography. Altogether, 100 volatile metabolites representing 78.97, 81.03, 85.78, and $84.49 \%$ of the total components present in EA, EP, FC, and HI oils, respectively, were reported. allo-Ocimene (14.55\%) was the major component in FC, followed by D-limonene (9.42\%). However, in EA, germacrene D (16.09\%) was present in a high amount, while heptanal $(36.89 \%)$ was the predominant compound in HI. The gas chromatographic data were subjected to principal component analysis (PCA) to explore the correlations between these species. Fortunately, the PCA score plot could differentiate between the species and correlate Ferula to Elaeosticta species. Additionally, the antioxidant activity was evaluated in vitro using the 2,2diphenyl-1-picryl-hydrazyl-hydrate (DPPH), 2,2-azino-bis(3-ethylbenzothiazoline-6-sulphonic acid) (ABTS), and the ferric reducing power (FRAP) assays. In addition, the antimicrobial activity using the agar diffusion method was assessed, and the minimum inhibitory concentrations (MICs) were determined. Furthermore, the cell viability MTT assay was performed to evaluate the cytotoxicity of the essential oils against hepatic (HepG-2) and cervical (HeLa) cancer cell lines. In the DPPH assay, FC exhibited the maximum activity against all the antioxidant assays with IC50 values of 19.8 and $23.0 \mu \mathrm{g} / \mathrm{mL}$ for the DPPH and ABTS assays, respectively. Ferula showed superior antimicrobial and cytotoxic activities as well. Finally, a partial least square regression model was constructed to predict the antioxidant capacity by utilizing the metabolite profiling data. The model showed excellent predictive ability by applying the ABTS assay.
\end{abstract}

Keywords: Apiaceae; Elaeosticta allioides; Elaeosticta polycarpa; Ferula clematidifolia; Hyalolaena intermedia; essential oils; biological activity

\section{Introduction}

Central Asia, particularly its hilly regions, is one of the richest and significantly diverse areas for the growth of family Apiaceae in the world. Kazakhstan, Kyrgyzstan, 
Tajikistan, Turkmenistan, and Uzbekistan are the habitats for about 458 species belonging to 110 genera of this family [1]. Interestingly, the Uzbek flora includes 231 species belonging to the family Apiaceae [2,3]. Many well-known plants belong to this family are widely used in culinary and therapeutic purposes such as anise, asafoetida, caraway, carrot, celery, coriander, cumin, dill, fennel, parsley, and many others. These plants are distinguished by the presence of volatile components that have long been regarded as scents with healing powers for body, mind, and soul with minimum side effects. Most of these essential oils components are potent antibacterial, antiviral, and antifungal agents [4].

Uzbekistan has approximately 100 species of Elaeostica, Ferula, and Hyalolaena, with nearly $25 \%$ of them being endemic and not found in any other places [5]. The local healers use many of these plants to treat infectious conditions, and they can also be used for culinary purposes [6]. However, the paucity of scientific data on their uses and concern that most of these plants may be endangered due to their massive consumption [7] initiated our interest in documenting their chemical compositions and biological activities.

The genus Hyalolaena Bunge is distributed around the lower Syr Darya river. Mountainous Central Asia is the focal center of diversity for Hyalolaena, of which nine species are widely distributed. Three species, $H$. bupleuroides (Schrenk) Pimenov \& Kljuykov, $H$. jaxartica, and H. trichophylla (Schrenk) Pimenov \& Kljuykov, have broad distribution ranges. Two species of Hyalolaena, namely $H$. bupleuroides and H. intermedia, are newly recorded in Uzbekistan [8]. These species are perennial monocarpic herbs with tuberiform, globose, obovate, cylindrical, or cordlike roots. Hyalolaena intermedia Pimenov and Kljuykov grows on rocks, red clay outcrops, clay-gravelly slopes, granite rocks at an altitude of 800-1200 m above sea level. It is distributed in the Western Tien Shan region, located in Kyrgyzstan and Uzbekistan [2].

Elaeosticta Fenzl is native to Ukraine to Central Asia and Western Himalayas. This genus contains at least 26 species [2,9], of which 15 species grow in Uzbekistan. Elaeosticta allioides (Regel \& Schmalh.) Kliuikov, Pimenov, and V. N. Tikhomirov is a perennial, monocarpic plant common in Central Asia and Northern Iran. It grows on soft slopes, less often on rocky terraces and channels, in belts of semi-deserts, and on dry grassy steppes at an altitude of 500-2100 m above sea level sedge-bluegrass. It blooms in May-June and bears fruits in July-August. Elaeosticta polycarpa (Korovin) Kliuikov, Pimenov, and V. N. Tikhomirov is common in Central Asia and Afghanistan. It grows in the foothills on soft grassy slopes in the belt of the ephemeral semi-desert on the border (Angren region). It blooms in May, bears fruits in June, and is mainly used as fodder. Many studies revealed that the aerial part of this species, which showed antibacterial activity, contains essential oil, while in the roots, saponins are common [10].

Ferula L. includes about 200 species of flowering plants. Many of these species are utilized for medicinal, nutritional, and fodder purposes. Most species of this genus contain a high number of essential oils and resins. There are 114 species in Central Asia and about 60 in Uzbekistan, of which 5 are endemic [11,12]. These species grow mainly in the mountains at relatively high altitudes at a level of 300 to $3600 \mathrm{~m}$ above sea level, both on fine-grained, variegated layers and gravelly slopes. These plants contain essential oils or resin-like substances, coumarins, flavonoids, and (rarely) saponins in their organs [12,13]. In the same context, F. clematidifolia Koso-Pol is a perennial, polycarpic plant distributed in the Pamir-Alai (Zeravshan ridge, Takhta-karacha, Hissar, Karategin, Babatag). It blooms in May-June and bears fruits in June-August. Some of these endemic species of Ferula were evaluated for their antioxidant and anti-inflammatory activities. The results showed that most Ferula species had moderate antioxidant activity [14].

There are no studies on the volatile components and the essential oils' compositions of Elaeosticta allioides, E. polycarpa, Ferula clematidifolia, and Hyalolaena intermedia growing in Uzbekistan. This study investigates the chemical composition of these species based on gas chromatography/mass spectrometry (GC-MS) analyses. Besides, chemotaxonomic discrimination between these species was conducted by applying multivariate analysis. In addition, the essential oils were evaluated for their antioxidant, antibacterial, and cytotoxic 
activities. Finally, a partial least square (PLS) regression model was constructed to investigate the correlation between the chromatographic fingerprint and the antioxidant activity.

\section{Results and Discussion}

\subsection{Chemical Composition Determination}

The chemical compositions of the essential oils collected from the aerial branches of four Apiaceae plants were determined by qualitative and semi-quantitative analyses using gas chromatography (GC) techniques. All of the oils are typical yellow with distinct smells. One hundred metabolites were identified (Table 1), representing 78.97, 81.03, 85.78, and $84.9 \%$ of the detected components in E. allioides, E. polycarpa, F. clemaditifolia, and $H$. intermedia essential oils, respectively.

Table 1. Chemical composition of essential oils in the aerial parts of E. allioides, E. polycarpa, F. clemaditifolia, and H. intermedia.

\begin{tabular}{|c|c|c|c|c|c|c|c|c|}
\hline \multirow[b]{2}{*}{ Heading } & \multirow[b]{2}{*}{ Compound } & \multirow{2}{*}{$\begin{array}{c}\text { RI, } \\
\text { Calculated }\end{array}$} & \multirow{2}{*}{$\begin{array}{c}\text { RI, } \\
\text { Reported }\end{array}$} & \multicolumn{4}{|c|}{ Peak Area (\%) } & \multirow{2}{*}{$\begin{array}{l}\text { Method of } \\
\text { Identifica- } \\
\text { tion }\end{array}$} \\
\hline & & & & $\begin{array}{c}\text { E. } \\
\text { allioides }\end{array}$ & $\begin{array}{c}E . \\
\text { polycarpa }\end{array}$ & $\begin{array}{l}\text { F. clemadi- } \\
\text { tifolia }\end{array}$ & $\begin{array}{c}H . \\
\text { intermedia }\end{array}$ & \\
\hline 1 & 1-Methyl-1,3-cyclohexadiene & 771 & 770 & 0.19 & 3.09 & tr. & 0.47 & MS, RI \\
\hline 2 & 3-Methylenecyclohexene & 792 & 791 & 0.52 & 9.46 & 0.43 & 1.53 & MS, RI \\
\hline 3 & 2-Hexanol & 807 & 801 & - & 1.52 & - & 1.12 & MS, RI \\
\hline 4 & n-Hexanal & 810 & 810 & 0.39 & 5.22 & 0.62 & 0.87 & MS, RI \\
\hline 5 & 3-Furaldehyde & 834 & 832 & - & - & - & 0.42 & MS, RI \\
\hline 6 & 3(Z)-Hexen-1-ol & 851 & 851 & 0.08 & - & 0.59 & 2.14 & MS, RI \\
\hline 7 & (E)-Salvene & 860 & 865 & 0.07 & 2.22 & 0.14 & tr. & MS, RI \\
\hline 8 & Santene & 886 & 884 & 0.08 & - & 0.01 & - & MS, RI \\
\hline 9 & Heptanal & 900 & 900 & 0.26 & 4.36 & - & 36.89 & MS, RI \\
\hline 10 & $\alpha$-Thujene & 929 & 929 & - & - & 3.75 & - & MS, RI, AU \\
\hline 11 & $\alpha$-Pinene & 939 & 939 & 0.32 & - & 1.24 & - & MS, RI, AU \\
\hline 12 & $\beta$-Citronellene & 947 & 947 & 0.15 & - & - & - & MS, RI, AU \\
\hline 13 & 2(Z)-Heptenal & 952 & 952 & - & - & - & 1.70 & MS, RI \\
\hline 14 & Camphene & 959 & 959 & 0.76 & - & - & - & MS, RI, AU \\
\hline 15 & 1-Heptanol & 962 & 966 & - & - & - & 1.22 & MS, RI \\
\hline 16 & Sabinene & 966 & 969 & 0.23 & - & - & tr. & MS, RI, AU \\
\hline 17 & Isopropyl tiglate & 979 & 981 & 0.13 & - & 0.17 & tr. & MS, RI \\
\hline 18 & 1-Octen-3-one & 986 & 986 & - & - & - & 2.12 & MS, RI \\
\hline 19 & $\beta$-Pinene & 988 & 988 & 0.80 & - & 2.24 & & MS, RI, AU \\
\hline 20 & 2,3-Dehydro-1,8-cineole & 997 & 994 & - & - & 0.08 & & MS, RI \\
\hline 21 & Octanal & 1002 & 1002 & 1.80 & - & - & 1.71 & MS, RI \\
\hline 22 & 2,4-(E,E)-Heptadienal & 1011 & 1011 & - & - & - & 0.37 & MS, RI \\
\hline 23 & $\alpha$-Phellandrene & 1013 & 1013 & - & tr. & 0.09 & tr. & MS, RI, AU \\
\hline 24 & $\begin{array}{l}\text { 1-(1-Cyclohexen-1-yl)- } \\
\text { ethanone }\end{array}$ & 1028 & 1023 & - & - & - & 1.47 & MS, RI \\
\hline 25 & p-Cymene & 1029 & 1029 & tr. & - & 5.09 & tr. & MS, RI, AU \\
\hline 26 & D-Limonene & 1034 & 1034 & 2.83 & tr. & 9.42 & 0.48 & MS, RI, AU \\
\hline 27 & Eucalyptol & 1039 & 1039 & - & - & - & 0.28 & MS, RI, AU \\
\hline 28 & $\beta$-(Z)-Ocimene & 1044 & 1045 & 0.57 & - & 0.22 & - & MS, RI \\
\hline 29 & Benzeneacetaldehyde & 1046 & 1046 & - & tr. & - & 1.44 & MS, RI \\
\hline 30 & $\beta$-(E)-Ocimene & 1052 & 1052 & - & 2.14 & - & tr. & MS, RI \\
\hline 31 & (3Z)-Octen-1-ol & 1056 & 1058 & - & tr. & - & 4.73 & MS, RI \\
\hline 32 & $\gamma$-Terpinene & 1062 & 1062 & 0.27 & - & 4.8 & - & MS, RI, AU \\
\hline 33 & cis-Linalool oxide & 1073 & 1073 & 0.28 & - & 2.19 & - & MS, RI \\
\hline 34 & trans-Linalool oxide & 1090 & 1090 & 0.31 & - & - & - & MS, RI \\
\hline 35 & p-Mentha-1,4(8)-diene & 1092 & 1092 & - & 1.20 & 0.88 & 0.97 & MS, RI \\
\hline 36 & Linalool & 1099 & 1099 & 1.35 & 4.11 & - & 1.33 & MS, RI, AU \\
\hline 37 & tetrahydro-Linalool & 1103 & 1099 & 0.21 & 2.92 & 9.02 & 0.8 & MS, RI \\
\hline 38 & cis-Thujone & 1107 & 1102 & - & - & 2.01 & - & MS, RI \\
\hline 39 & trans-Thujone & 1112 & 1112 & - & 1.98 & - & - & MS, RI \\
\hline 40 & allo-Ocimene & 1126 & 1127 & 0.15 & tr. & 14.55 & 0.22 & MS, RI \\
\hline 41 & p-Menth-2-en-1-ol & 1130 & 1130 & 0.08 & - & 0.16 & - & MS, RI \\
\hline 42 & cis-p-Mentha-2,8-dien-1-ol & 1140 & 1141 & 0.16 & - & - & - & MS, RI \\
\hline 43 & (E)-2-Nonenal & 1159 & 1159 & 0.28 & tr. & - & 4.24 & MS, RI \\
\hline 44 & Borneol & 1165 & 1165 & 0.21 & - & 0.15 & - & MS, RI, AU \\
\hline 45 & Menthol & 1167 & 1171 & - & - & - & 1.71 & MS, RI, AU \\
\hline 46 & 4-Terpineol & 1174 & 1174 & 0.19 & - & 6.39 & - & MS, RI, AU \\
\hline 47 & $\alpha$-Terpineol & 1186 & 1186 & 0.28 & - & 3.33 & - & MS, RI, AU \\
\hline 48 & trans-Carveol & 1223 & 1223 & 0.41 & - & - & - & MS, RI \\
\hline 49 & $\beta$-Cyclocitral & 1225 & 1224 & - & - & - & 0.33 & MS, RI \\
\hline 50 & Citronellol & 1229 & 1229 & - & - & 6.94 & - & MS, RI \\
\hline
\end{tabular}


Table 1. Cont.

\begin{tabular}{|c|c|c|c|c|c|c|c|c|}
\hline \multirow[b]{2}{*}{ Heading } & \multirow[b]{2}{*}{ Compound } & \multirow{2}{*}{$\begin{array}{c}\text { RI, } \\
\text { Calculated }\end{array}$} & \multirow{2}{*}{$\begin{array}{c}\text { RI, } \\
\text { Reported }\end{array}$} & \multicolumn{4}{|c|}{ Peak Area (\%) } & \multirow{2}{*}{$\begin{array}{l}\text { Method of } \\
\text { Identifica- } \\
\text { tion }\end{array}$} \\
\hline & & & & $\begin{array}{c}E . \\
\text { allioides }\end{array}$ & $\begin{array}{c}E . \\
\text { polycarpa }\end{array}$ & $\begin{array}{l}\text { F. clemadi- } \\
\text { tifolia }\end{array}$ & $\begin{array}{c}H . \\
\text { intermedia }\end{array}$ & \\
\hline 51 & Neral & 1239 & 1239 & 0.04 & - & 0.07 & 0.31 & MS, RI, AU \\
\hline 52 & Geraniol & 1249 & 1250 & 0.56 & - & 0.31 & 0.79 & MS, RI, AU \\
\hline 53 & Linalool acetate & 1253 & 1254 & 0.04 & - & 0.04 & 0.36 & MS, RI \\
\hline 54 & 2(E)-Decenal & 1262 & 1263 & 0.83 & - & - & 1.03 & MS, RI \\
\hline 55 & dihydro-Linalool acetate & 1275 & 1271 & 0.06 & 2.41 & 0.07 & 0.50 & MS, RI \\
\hline 56 & Bornyl acetate & 1290 & 1290 & 3.60 & - & 0.06 & - & MS, RI \\
\hline 57 & Undecanal & 1316 & 1313 & & 1.29 & - & 1.53 & MS, RI \\
\hline 58 & p-Mentha-1,4-dien-7-ol & 1329 & 1329 & - & 6.71 & 0.12 & 1.01 & MS, RI \\
\hline 59 & $\delta$-Terpinyl acetate & 1340 & 1340 & 0.09 & 1.57 & 0.11 & 0.57 & MS, RI \\
\hline 60 & $\alpha$-Longipinene & 1355 & 1355 & 0.11 & - & 0.12 & - & MS, RI \\
\hline 61 & $\beta$-Patchoulene & 1387 & 1382 & 0.31 & - & 0.24 & - & MS, RI \\
\hline 62 & $\beta$-Bourbonene & 1397 & 1394 & 0.52 & - & - & - & MS, RI \\
\hline 63 & $\beta$-Caryophyllene & 1433 & 1433 & 0.54 & - & 1.4 & 0.38 & MS, RI, AU \\
\hline 64 & Aromandendrene & 1449 & 1447 & 0.08 & - & 0.06 & - & MS, RI, AU \\
\hline 65 & $\alpha$-Humulene & 1469 & 1469 & 0.25 & - & 0.26 & - & MS, RI \\
\hline 66 & $\gamma$-Muurolene & 1485 & 1486 & 1.35 & - & 0.28 & 1.17 & MS, RI \\
\hline 67 & Germacrene D & 1494 & 1496 & 16.09 & - & - & - & MS, RI \\
\hline 68 & $\alpha$-Cuprenene & 1503 & 1505 & tr. & - & tr. & - & MS, RI \\
\hline 69 & Germacrene A & 1506.4 & 1506 & 1.51 & - & tr. & 0.27 & MS, RI \\
\hline 70 & $\gamma$-Cadinene & 1509 & 1509 & - & - & 1.16 & - & MS, RI \\
\hline 71 & Cubebol & 1513 & 1513 & 0.21 & - & - & 0.52 & MS, RI \\
\hline 72 & $\delta$-Cadinene & 1522 & 1522 & tr. & - & - & 1.1 & MS, RI \\
\hline 73 & $\gamma$-Cuprenene & 1527 & 1523 & 2.12 & - & 0.61 & & MS, RI \\
\hline 74 & $\alpha$-Cadinene & 1533 & 1538 & 0.32 & 3.41 & 0.11 & tr. & MS, RI \\
\hline 75 & (-)-Spathulenol & 1577 & 1576 & 2.51 & - & - & & MS, RI \\
\hline 76 & Caryophyllene oxide & 1582 & 1582 & 1.45 & - & 0.82 & 0.37 & MS, RI, AU \\
\hline 77 & Salvial-4(14)-en-1-one & 1607 & 1604 & 2.46 & - & - & - & MS, RI \\
\hline 78 & Humulene epoxide II & 1621 & 1620 & 1.80 & - & - & - & MS, RI \\
\hline 79 & $\beta$-Himachalene oxide & 1627 & 1613 & 1.59 & tr. & - & - & MS, RI \\
\hline 80 & 1-epi-Cubenol & 1638 & 1632 & 1.18 & - & 0.06 & - & MS, RI \\
\hline 81 & $\beta$-Eudesmol & 1657 & 1654 & 2.51 & - & - & - & MS, RI \\
\hline 82 & $\alpha$-Cadinol & 1667 & 1667 & 2.06 & - & 0.08 & - & MS, RI \\
\hline 83 & $\beta$-Bisabolol & 1676 & 1675 & 3.04 & - & - & - & MS, RI \\
\hline 84 & Apiole & 1678 & 1679 & - & - & 0.27 & 0.57 & MS, RI \\
\hline 85 & $\alpha$-Bisabolone oxide A & 1688 & 1686 & - & - & 0.15 & - & MS, RI \\
\hline 86 & $\alpha$-Bisabolol & 1690 & 1695 & 4.17 & - & - & 0.62 & MS, RI, AU \\
\hline 87 & Germacrone & 1696 & 1696 & - & 1.72 & 0.36 & tr. & MS, RI \\
\hline 88 & Caryophyllene acetate & 1704 & 1704 & 4.25 & - & - & - & MS, RI \\
\hline 89 & Cedr- $8(15)$-en- $9 \alpha$-ol, acetate & 1745 & 1743 & 0.37 & 3.14 & 0.08 & 0.64 & MS, RI \\
\hline 90 & $\alpha$-Bisabolol oxide A & 1753 & 1746 & 0.37 & 1.14 & - & - & MS, RI \\
\hline 91 & Benzyl benzoate & 1779 & 1775 & tr. & 2.84 & 0.06 & 0.66 & MS, RI \\
\hline 92 & $\beta$-Bisabolenal & 1785 & 1765 & 4.07 & - & & - & MS, RI \\
\hline 93 & Cedryl methyl ketone & 1791 & 1791 & 1.00 & - & 0.03 & - & MS, RI \\
\hline 94 & $\beta$-Bisabolenol & 1806 & 1790 & 1.41 & - & 0.08 & - & $\mathrm{MS}, \mathrm{RI}$ \\
\hline 95 & $\begin{array}{l}\text { Methyl-hexadecanoic acid } \\
\text { ester }\end{array}$ & 1923 & 1924 & 1.18 & - & 1.3 & - & MS, RI \\
\hline 96 & Hexadecanoic acid & 1956 & 1958 & 0.71 & 4.83 & 1.58 & 2.67 & MS, RI \\
\hline 97 & Phytol & 2110 & 2112 & 0.18 & 2.57 & 0.33 & - & MS, RI \\
\hline 98 & Methyl stearate & 2125 & 2128 & 0.46 & 1.48 & 0.95 & - & MS, RI \\
\hline 99 & Ethyl octadecanoate & 2165 & 2188 & 0.05 & 1.98 & 0.06 & - & MS, RI \\
\hline \multirow[t]{11}{*}{100} & Hinokiol & 2590 & 2590 & 0.16 & 7.72 & 0.04 & 0.86 & MS, RI \\
\hline & Monoterpenes & & & 5.93 & 3.34 & 42.28 & 1.67 & \\
\hline & Oxygenated monoterpenes & & & 8.02 & 19.7 & 31.05 & 7.99 & \\
\hline & Sesquiterpenes & & & 23.2 & 3.41 & 4.24 & 2.92 & \\
\hline & Oxygenated sesquiterpenes & & & 34.45 & 6 & 1.66 & 2.15 & \\
\hline & Alkenes & & & 0.80 & 11.68 & 0.75 & 1.53 & \\
\hline & Alcohols & & & 0.42 & 11.81 & 1.23 & 10.64 & \\
\hline & Aldehyde and ketones & & & 3.56 & 10.87 & 0.62 & 53.79 & \\
\hline & Fatty acids and their esters & & & 2.40 & 8.29 & 3.89 & 2.67 & \\
\hline & Others & & & & 2.84 & 0.06 & 0.66 & \\
\hline & Total identified & & & 78.97 & 81.03 & 85.78 & 84.49 & \\
\hline
\end{tabular}

Compounds were identified based on the compounds' mass spectral data (MS), and retention indices (RI), compared with those of the NIST Mass Spectral Library (December 2011), the Wiley Registry of Mass Spectral Data, 8th edition, and many authentic standards (AU). The content $(\%)$ was calculated using the normalization method based on the GC-MS data. The presented data is the average of three replicas (tr. = trace, concentration less than $0.01 \%$ ) 
These essential oils demonstrated a high degree of metabolic variability, both qualitatively and quantitatively. allo-Ocimene was the main compound in F. clemaditifolia, with the highest percentage $(14.55 \%)$, followed by D-limonene (9.42\%) and tetrahydro-linalool (9.02\%). In E. allioides, germacrene D (16.09\%), caryophyllene acetate $(4.25 \%), \alpha$-bisabolol $(4.17 \%)$, and $\beta$-bisabolenal $(4.07 \%)$ were representing the major identified components. However, 3methylenecyclohexene (9.46\%), hinokiol (7.72\%), and p-mentha-1,4-dien-7-ol (6.71\%) were the main compounds detected in E. polycarpa. Concerning, H. intermedia, heptanal (36.89\%), (3Z)-octen-1-ol (4.73\%), and (E)-2-nonenal (4.24\%) were the predominant compounds.

Monoterpenes and oxygenated monoterpenes are the predominant classes of metabolites detected in the F. clemaditifolia essential oil, where they represent 42.28 and 31.05\% of the total components, respectively. Similar results could be noticed with these classes in many Ferula species. For instance, terpinolene $(77.62 \%)$ was the major component in $F$. macrecolea [15], while $\beta$-pinene $(60.84 \%)$ was the predominant metabolite in F. gummosa [16]. In F. tunetana, $\alpha$-pinene (39.8\%) was the main component [17] and $\alpha$-thujene (13.5\%) is present in the highest concentration in F. tingitana [18]. On the same context, these results were following our previous studies on other Ferula species where D-limonene was a major identified component in 6 different Ferula species [19]. These diverse metabolic profiles of Ferula, can be attributed to the wide spread of the genus in many continents and the subsequent great variability in the climatic and the soil characteristics, which have a great impact on the essential oils composition in the plants [20].

Oxygenated monoterpenes are also the main class in E. polycarpa, representing 19.7\% of the detected components in its essential oil. However, oxygenated sesquiterpenes are the dominant class of metabolites in E. allioides (34.45\%). Rare studies were carried out on this small genus. Hamedi et al. studied the essential oil composition of E. glaucescens [21]. The aliphatic ester constituted $52.0 \%$, followed by the sesquiterpene hydrocarbon $(6.1 \%)$, which are the major reported classes of the secondary metabolites. Conversely, aldehyde and ketones are highly predominant in $H$. intermedia, accounting for $53.79 \%$ of the identified components. It was the first report on the chemical composition of the volatile components in the genus.

\subsection{Multivariate Data Analysis \\ Explorative Data Analysis}

A useful approach for differentiation between closely related species is applying multivariate analysis based on various chromatographic techniques [22,23]. Multivariate analysis was used based on the GC data to determine the relationships between these Apiaceae species and explore similarities and dissimilarities between them. Principal Component Analysis (PCA) was primarily used to categorize data and to find correlations between samples and variables. After that, Hierarchical Cluster Analysis (HCA) was used for sorting samples into clusters based on their vicinity to each other. The relative peak areas of all compounds in the chromatograms from the studied species were subjected to both PCA and HCA analyses.

The score and loading plots for the data set are shown in Figure 1. The PCA scores plot for principal components (PCs), namely PC1 versus PC2, is shown in Figure 1a. The total variance of $82 \%$ was explained with two PCs. Different Apiaceae species could be discriminated from each other into three main groups, where they are positioned at three different quadrants. Both F. clemaditifolia and H. intermedia were positioned in separate quadrants highlighting their obvious dissimilarity from the remaining species. However, the PCA score plot showed F. clemaditifolia closeness to genus Elaeosticta, as both were positively correlated to PC1. This correlation may be attributed to the chemotaxonomic similarity due to common components such as D-limonene, dihydro-linalool acetate, hexadecanoic acid, phytol, methyl stearate, and ethyl octadecanoate. This correlation is quite interesting as it is the first chemotaxonomic classification carried out on these two species. Most morphological and anatomical classifications typically correlate both Hyalolaena and Elaeosticta genera together, and Ferula is usually separated [24]. These results encourage 
researchers to perform more studies on the chemotaxonomy of Apiaceae. Moreover, $E$. allioides and E. polycarpa were falling together in the same upper quadrant distanced from each other (as both are from the same genus). By clear inspection of the loading plot Figure $1 \mathrm{~b}$, it revealed the effective variables for each PCs where allo-ocimene, heptanal, and germacrene $\mathrm{D}$ were the key makers accountable for the segregation of F. clemaditifolia, H. intermedia, and E. allioides, E. polycarpa, respectively.
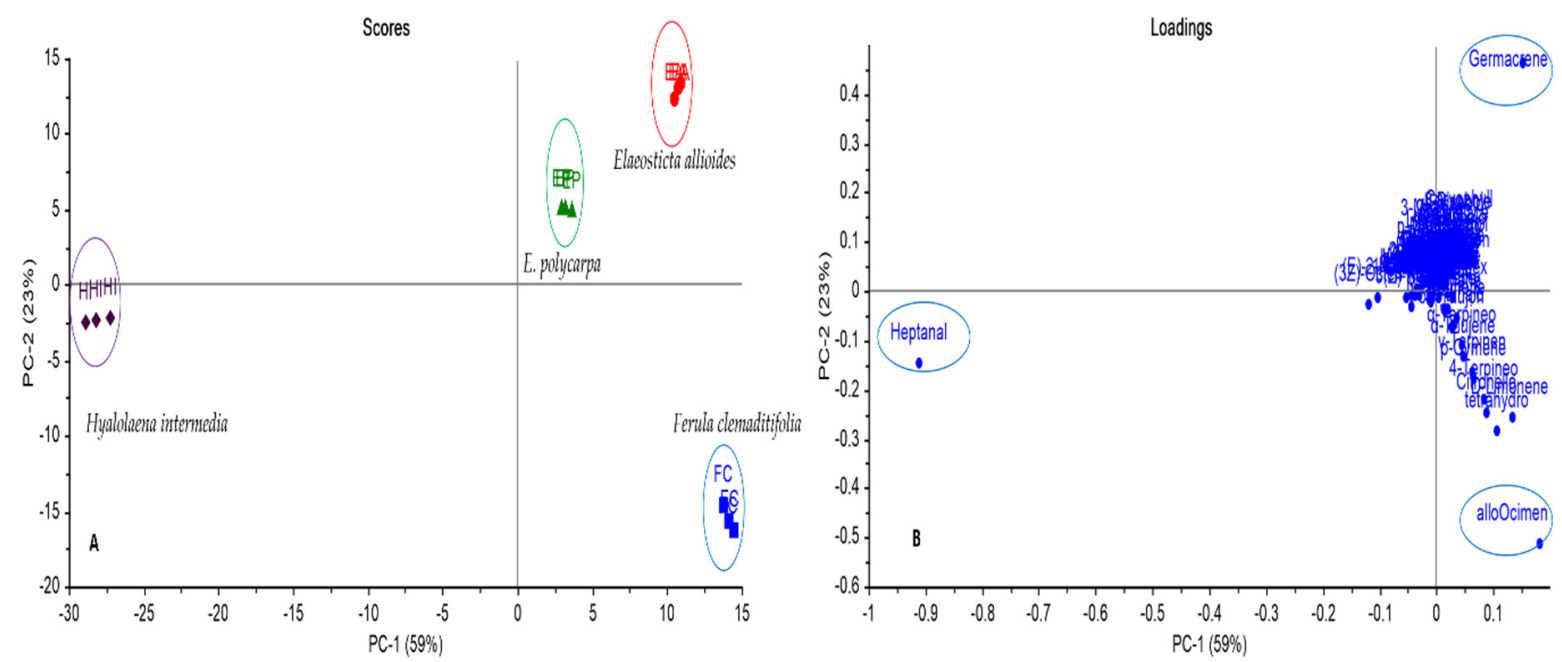

Figure 1. Principal Component Analysis score plot (A) and loading plot (B) of GC-MS analysis of essential oils of different Apiaceae species based on the identification of compounds shown in Table 1. E. allioides (EA), E. polycarpa (EP), F. clemaditifolia (FC), and H. intermedia (HI).

HCA clustering was performed to have a better insight into species classification. Figure 2 shows the HCA dendrogram for GC fingerprints. HCA dendrogram clustered Apiaceae species into three main clusters. Cluster I, II, and III displayed F. clemaditifolia, $H$. intermedia and E. allioides, E. polycarpa, respectively. The dendrogram confirmed the results obtained from PCA, revealing the similarity of E. allioides and E. polycarpa as both grouped in one cluster.

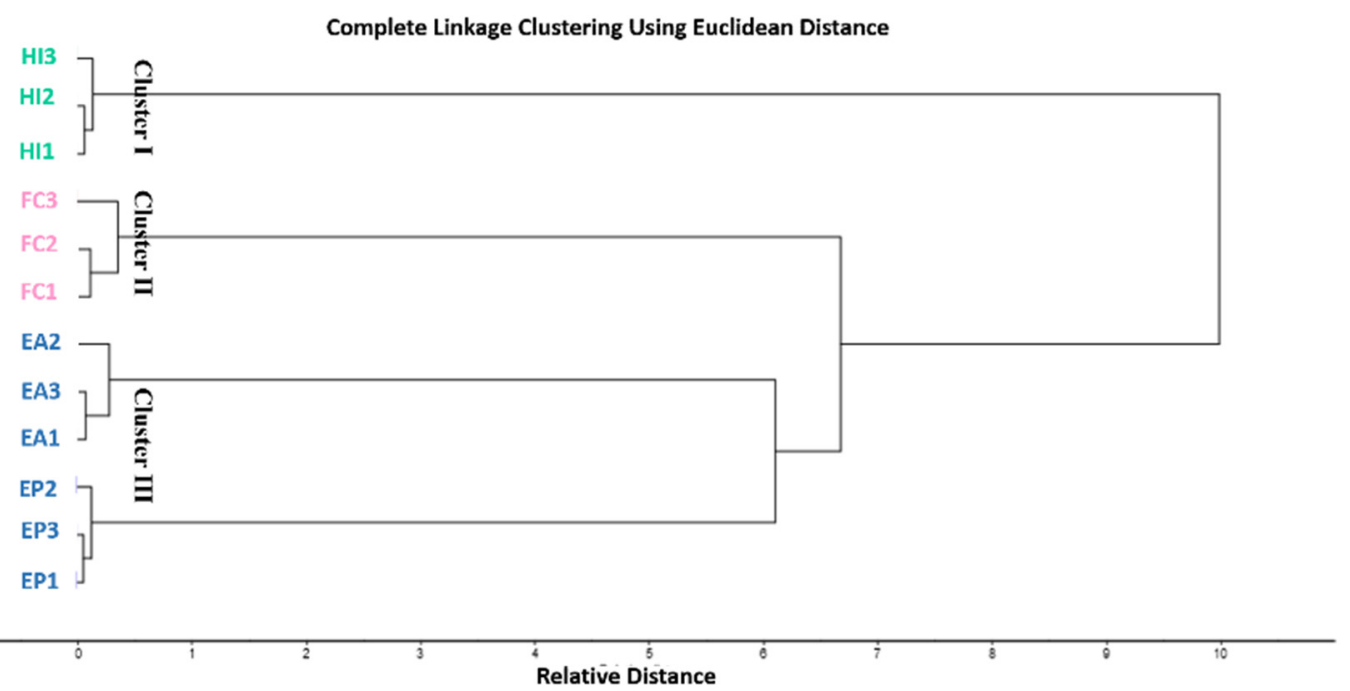

Figure 2. HCA of GC analysis of essential oils of different Apiaceae species based on the identification of the compounds shown in Table 1. E. allioides (EA), E. polycarpa (EP), F. clemaditifolia (FC), and $H$. intermedia (HI). 


\subsection{Biological Activities}

\subsubsection{Antibacterial Activity}

The disc diffusion and micro-dilution techniques were applied to investigate the antimicrobial activity of the essential oils obtained from the aerial parts of $F$. clemaditifolia, E. allioides, E. polycarpa, and H. intermedia. Staphylococcus aureus (ATCC 25923), and Pseudomonas aeruginosa (ATCC 85327) were used as representatives of Gram-positive and Gram-negative bacteria, respectively. The mean diameter of inhibition zones (DIZ) and the minimum inhibition concentrations (MIC) values were determined, and the results were presented in Table 2. Three of the studied essential oils showed significantly low antimicrobial activity against the examined bacterial strains with MIC values $>500 \mu \mathrm{g} / \mathrm{mL}$. However, F. clemaditifolia oil exerted promising activity comparable to other tested oils with MICs values of $125 \mu \mathrm{g} / \mathrm{mL}$ against the Gram-positive S. aureus strains. These results were following previously reported data for the antiinfective activity of the essential oils obtained from six other Ferula species that exhibited moderate antimicrobial activity [18,25-27]. At the same time, nothing could be found in the literature related to the antibacterial activity of the other two genera Elaeosticta or Hyalolaena, and here we report for the first time about their biological activities. Although many studies deal with the exact mechanism of antibacterial activities of many essential oils and their components, it is not easy to correlate the activity to a single component. These oils are a complex mixture composed of many active ingredients that work synergistically at many targets in the microbes. Most of the volatile secondary metabolites can diffuse through the bacteria's cell membranes, leading to destructing many organelles, morphological changes, and interference of the respiratory chain, causing bacterial death [28]. This promising activity of Ferula compared to other oils may be attributed to the high content of the oxygenated monoterpenes, especially linalool, citronellol, allo-ocimene, and 4-terpineol. These compounds were reported to have a relevant bactericidal activity against a wide range of Gram-positive and Gram-negative bacteria [29-33].

Table 2. Minimum inhibitory concentrations (MIC) in $(\mu \mathrm{g} / \mathrm{mL})$ and mean diameter of inhibition zones (DIZ) in (mm) of $E$. allioides, E. polycarpa, F. clemaditifolia, and H. intermedia essential oils against different pathogens determined by microdilution and agar diffusion method.

\begin{tabular}{|c|c|c|c|c|c|c|c|c|c|c|}
\hline \multirow[b]{2}{*}{ Microorganisms } & \multicolumn{2}{|c|}{ E. allioides } & \multicolumn{2}{|c|}{ E. polycarpa } & \multicolumn{2}{|c|}{ F. clematidifolia } & \multicolumn{2}{|c|}{ H. intermedia } & \multicolumn{2}{|c|}{ Positive Control * } \\
\hline & $\begin{array}{c}\text { DIZ } \\
(\mathrm{mm})\end{array}$ & $\underset{(\mu \mathrm{g} / \mathrm{mL})}{\mathrm{MIC}}$ & $\begin{array}{c}\text { DIZ } \\
(\mathrm{mm})\end{array}$ & $\underset{(\mu \mathrm{g} / \mathrm{mL})}{\mathrm{MIC}}$ & $\begin{array}{c}\text { DIZ } \\
(\mathrm{mm})\end{array}$ & $\underset{(\mu \mathrm{g} / \mathrm{mL})}{\mathrm{MIC}}$ & $\begin{array}{c}\text { DIZ } \\
(\mathrm{mm})\end{array}$ & $\underset{(\mu \mathrm{g} / \mathrm{mL})}{\mathrm{MIC}}$ & $\begin{array}{c}\text { DIZ } \\
(\mathrm{mm})\end{array}$ & $\underset{(\mu \mathrm{g} / \mathrm{mL})}{\mathrm{MIC}}$ \\
\hline $\begin{array}{l}\text { Gram-positive bacteria } \\
\text { S. aureus ATCC } 25923 \\
\text { Gram negative bacteria }\end{array}$ & $10.8 \pm 0.4$ & $>500$ & $11.7 \pm 0.5$ & $>500$ & $19.4 \pm 0.1$ & 125 & $11.8 \pm 0.6$ & $>500$ & $30.1 \pm 0.6$ & 0.16 \\
\hline P. aeruginosa ATCC 85327 & $8.3 \pm 0.2$ & $>500$ & $9.3 \pm 03$ & $>500$ & $9.6 \pm 0.4$ & 250 & $15.1 \pm 0.3$ & $>500$ & $24.7 \pm 0.3$ & 0.24 \\
\hline
\end{tabular}

Data are presented as means \pm S.D. $n=3 ;{ }^{*}$ The positive control was taken as ampicillin for Gram-positive bacteria and gentamycin for Gram-negative bacteria; In all assays, $30 \mathrm{mg}$ essential oil, $10 \mu \mathrm{g}$ of the standard antibiotic in $1 \mathrm{~mL}$ DMSO, and $100 \mu \mathrm{L}$ were applied. DIZ, the diameter of inhibition zone is measured in $(\mathrm{mm})$ by the agar diffusion method.

\subsubsection{Antioxidant Activity}

The DPPH, ABTS, and FRAP assays were used to determine the in vitro antioxidant activity of the essential oils. The IC50 values of the antioxidant activity of the essential oils obtained from the aerial parts of F. clemaditifolia, E. allioides, E. polycarpa, and H. intermedia and ascorbic acid as a positive control were displayed in Table 3. In all the experiments used, F. clematidifolia showed superior antioxidant activity with IC50 values of 19.8 and $23.0 \mu \mathrm{g} / \mathrm{mL}$ for the DPPH and ABTS assays, respectively. In the FRAP assay, it exhibited a substantial reducing power of $1308.1 \pm 8.9 \mathrm{mM} \mathrm{Fe}(\mathrm{II}) / \mathrm{g}$. In general, measuring the antioxidant activity by in vitro experiments depends on the power of the sample to scavenge the generated free radicals produced by the system. Phenolic compounds such as acids and flavonoids are the main target secondary metabolites that can strongly suppress these active species. However, oxygenated hydrocarbons can also work in the same context, but to a lesser extent [34]. Regarding the studied samples, the absence of high content of phenolic compounds is the main cause of the moderate antioxidant activity. However, 
the antioxidant effect may be attributed to the whole oxygenated components of the oils. Similar results for Ferula species were explained in previous work based on the mechanism of preventing the free-radical initiation and decomposition of the peroxide radicals $[35,36]$. Our results are following the previously published data about the antioxidant activity of Ferula assafoetida oleo-gum-resin. Both Ferula essential oils showed promising antioxidant activity with IC50 values ranging from 10-50 $\mu \mathrm{g} / \mathrm{mL}$ [37].

Table 3. IC50 values $(\mu \mathrm{g} / \mathrm{mL})$ for the antioxidant activities of the essential oils obtained from $E$. allioides, E. polycarpa, F. clemaditifolia, and H. intermedia using the DPPH, ABTS, and FRAP assays.

\begin{tabular}{cccc}
\hline \multirow{2}{*}{ Sample } & DPPH & ABTS & FRAP \\
\cline { 2 - 4 } & IC50 $(\mu \mathrm{g} / \mathbf{m L})$ & IC50 $(\boldsymbol{\mu g} / \mathbf{m L})$ & $\mathbf{m M ~ F e S O}_{\mathbf{4}} / \mathbf{g}$ Sample \\
\hline E. allioides & $95.1 \pm 3.6$ & $102.7 \pm 0.9$ & $1034.2 \pm 16.4$ \\
E. polycarpa & $136.0 \pm 8.9$ & $127.8 \pm 6.4$ & $998.8 \pm 11.2$ \\
F. clematidifolia & $19.8 \pm 0.6$ & $23.0 \pm 1.7$ & $1308.1 \pm 8.9$ \\
H. intermedia & $35.3 \pm 2.9$ & $39.2 \pm 1.0$ & $843.5 \pm 6.7$ \\
Ascorbic acid & $0.27 \pm 0.0$ & $6.9 \pm 0.2$ & $3421.3 \pm 29.3$ \\
\hline
\end{tabular}

Data are presented as means \pm S.D. $n=3$.

\subsubsection{Cytotoxic Activity}

The 3-(4,5-dimethylthiazol-2-yl)-2,5-diphenyltetrazolium bromide (MTT) assay was used to assess the cytotoxic activity of the essential oils obtained from E. allioides, E. polycarpa, F. clemaditifolia, $H$. intermedia, and the standard drug doxorubicin against two different cancer cells (HeLa and HepG-2). Most of the evaluated oils showed moderate activity against HeLa cells with IC50 values 138.5-171.2 $\mu \mathrm{g} / \mathrm{mL}$. F. clemaditifolia was the most potent cytotoxic agent among these oils against both HeLa and HepG-2 with IC50 values of 138.5 and $252.2 \mu \mathrm{g} / \mathrm{mL}$, respectively. However, E. allioides showed the weakest activity with IC50 values of 233.1 and $387.4 \mu \mathrm{g} / \mathrm{mL}$, respectively. Nevertheless, it is important to highlight that all the tested oils showed very weak anti-proliferative effect against HepG-2 cells, with IC50 values 252.2-387.4 $\mu \mathrm{g} / \mathrm{mL}$ compared to HeLa cells as reported in Table 4 . The cytotoxic properties of $F$. clemaditifolia may result from the synergistic action of the different constituents, including limonene, eucalyptol, linalool, 4-terpineol, and citronellol [38-43]. These components have been reported to specifically target many vital pathways and processes inside cancer cells, including apoptosis, cell cycle arrest, membrane damage, DNA synthesis inhibition, and ABC transporter modulation [44]. This pattern of antiproliferative activity is typically noticed with Zanthoxylum essential oil. This oil has a similar metabolic profile, and the activity was referred to the ability to induce $S$ phase arrest apoptosis and increase the expression of cleaved caspases in HaCaT cells [45].

Table 4. IC50 values $(\mu \mathrm{g} / \mathrm{mL})$ for the cytotoxic activity of the essential oils obtained from E. allioides, $E$. polycarpa, F. clemaditifolia, and H. intermedia against HeLa and HepG-2 cell lines using the MTT assay.

\begin{tabular}{ccc}
\hline Sample & HeLa & HepG-2 \\
\hline E. allioides & $233.1 \pm 8.6$ & $387.4 \pm 13.0$ \\
E. polycarpa & $156.3 \pm 10.2$ & $298.1 \pm 9.1$ \\
F. clematidifolia & $138.5 \pm 3.9$ & $252.2 \pm 12.4$ \\
H. intermedia & $171.2 \pm 10.3$ & $291.7 \pm 15.9$ \\
Doxorubicin $(\mu \mathrm{M})$ & $2.1 \pm 0.14$ & $0.78 \pm 0.05$ \\
\hline
\end{tabular}

Data are presented as means \pm S.D. $n=3$.

\subsection{Partial Least Square Regression Analysis}

Partial least square regression (PLS-R) analysis was conducted to establish a link between the gas chromatography fingerprints and their antioxidant activities of various studied species. PLS-R model was constricted by the data matrix $X$ containing the peak area of the GC fingerprints and the response vector y containing the antioxidant activity data. The ideal number of latent variables (LVs) in the PLS model was calculated using 
minimum root mean square error (RMSE) values obtained by cross-validation (CV). The performance of the model was assessed by the parameters of root mean square error of calibration (RMSEC), root mean square error of validation (RMSEV), and correlation $\left(R^{2}\right)$. The PLS-R model parameters, including slope, offset, RMSEC, RMSEV, and $\mathrm{R}^{2}$, have been shown in Table 5, indicating a superior prediction ability of the PLS regression model. PLS-R models showed excellent linearity and accuracy with $R^{2}>0.99$, slope close to 1 , intercept close to 0, low RMSEC and RMSEV (close to 0), and low differences between RMSEC and root mean square error of prediction (RMSEP) reveal the robustness of the model. In general, while employing ABTS data, the RMSEV value was less, implying that ABTS findings are more representative than other techniques used to assess antioxidant activity. The prediction performance for the developed models was shown in Table 6 . The results showed that the antioxidant activity is correctly predicted with $\pm 5 \%$ accuracy.

Table 5. The partial least square regression model parameters used for prediction.

\begin{tabular}{cccccc}
\hline \multirow{2}{*}{$\begin{array}{c}\text { Antioxidant } \\
\text { Activity }\end{array}$} & Data Type & \multicolumn{3}{c}{ PLS } \\
\cline { 3 - 6 } & & Slope & Offset & RMSE & $\mathbf{R}^{\mathbf{2}}$ \\
\hline \multirow{2}{*}{ DPPH } & Cal. & 0.9999 & 0.0065 & 0.4452 & 0.9999 \\
& Val. & 0.9995 & 0.0401 & 0.6581 & 0.9998 \\
\hline \multirow{2}{*}{ ABTS } & Cal. & 0.9999 & 0.0055 & 0.3760 & 0.9999 \\
& Val. & 0.9995 & 0.0415 & 0.5542 & 0.9998 \\
\hline \multirow{2}{*}{ FRAP } & Cal. & 0.9999 & 0.0307 & 0.9083 & 0.9999 \\
& Val. & 0.9995 & 0.3915 & 1.3430 & 0.9999 \\
\hline
\end{tabular}

RMSE, root mean squared error; $\mathrm{R}^{2}$, Correlation; Cal., Calibration; Val., Validation.

Table 6. Results of calibration and predictive ability of the partial least square model.

\begin{tabular}{ccccccc}
\hline & \multicolumn{2}{c}{ DPPH } & \multicolumn{2}{c}{ ABTS } & \multicolumn{2}{c}{ FRAP } \\
\cline { 2 - 7 } Heading & $\begin{array}{r}\text { Y } \\
\text { Reference }\end{array}$ & $\begin{array}{c}\text { Predicted } \\
\text { PC1 }\end{array}$ & $\begin{array}{c}\text { Y } \\
\text { Reference }\end{array}$ & $\begin{array}{c}\text { Y } \\
\text { Predicted }\end{array}$ & $\begin{array}{c}\text { Y } \\
\text { Reference }\end{array}$ & $\begin{array}{c}\text { Y } \\
\text { Predicted }\end{array}$ \\
\hline FC2 & 19.8 & 19.71874 & 23 & 22.94632 & 1308.1 & 1308.702 \\
FC3 & 19.4 & 20.47383 & 22.8 & 23.69492 & 1307.9 & 1305.79 \\
EA1 & 20.2 & 19.22362 & 23.3 & 22.47157 & 1309.2 & 1310.675 \\
EA2 & 95.1 & 95.12069 & 102.7 & 102.7001 & 1034.2 & 1034.095 \\
EA3 & 94.99 & 95.0702 & 102.4 & 102.6058 & 1034 & 1034.468 \\
EP1 & 13.2 & 95.09119 & 102.9 & 102.6873 & 1034.5 & 1034.145 \\
EP2 & 135.8 & 136.0015 & 127.8 & 127.7339 & 998.8 & 998.6842 \\
EP3 & 136.2 & 135.6428 & 127.4 & 127.4543 & 998.5 & 999.4387 \\
HI1 & 35.3 & 35.3489 & 128 & 128.0072 & 998.9 & 998.0963 \\
HI2 & 35 & 35.32335 & 39.2 & 39.18572 & 843.5 & 843.4024 \\
HI3 & 35.6 & 35.29141 & 39.4 & 39.24232 & 843.2 & 843.9583 \\
\hline
\end{tabular}

\section{Materials and Methods}

\subsection{Plant Material}

Elaeosticta allioides (Sample No. 27052019340) and Elaeosticta polycarpa (Sample No. 27052019335) aerial parts were collected in May 2019 from the Surkhandarya area (Babatag, 38.044681 N; 68.140031 E). Hyalolaena intermedia (Sample No. 310520156) was collected in spring 2019 from the Namangan region (Kosonsoy, 41.263346 N; 71.489287 E), while Ferula clematidifolia (Sample No. 15062019340) was collected in summer 2019 also from the Surkhandarya area (Babatag, 38.055475 N; 68.154019E), Uzbekistan. Pimenov, M.G. and Malsev I.I. authenticated the plant samples and placed voucher specimens at Uzbekistan National Herbarium. 


\subsection{Essential Oil Isolation}

At room temperature, the aerial parts of E. allioides, E. polycarpa, $H$. intermedia, and F. clematidifolia were air-dried in the shade for one week (moisture content not exceeding 10-12\%). The dried plant samples (300 g each) were hydro-distilled for $2 \mathrm{~h}$ using a Clevenger-type apparatus, yielding $0.14,0.12,0.19$ and $0.38 \% v / w$, respectively, after being trapped in dichloromethane. The oils were dried by passing over anhydrous sodium sulfate and kept at $-4{ }^{\circ} \mathrm{C}$ until being used for further experiments.

\subsection{Gas Chromatography Analysis}

Gas chromatography (GC) was performed on an Agilent 7890B gas chromatograph equipped with a DB-5Ms fused silica column $(30 \mathrm{~m} \times 0.25 \mathrm{~mm}$, film thickness $0.25 \mu \mathrm{m}$, Agilent Technologies, Middelburg, The Netherlands), which interfaced with an Agilent mass selective detector 5977A (Agilent Technologies, Middelburg, The Netherlands). The interface temperature was $280^{\circ} \mathrm{C}$; the source temperature was $230^{\circ} \mathrm{C}$; ionization energy: $70 \mathrm{eV}$; and the scan range: $45-950$ atomic mass units. A GC autosampler was used to inject $0.5 \mu \mathrm{L}$ of the sample. The temperature programming was set to supply an oven temperature at $50^{\circ} \mathrm{C}$ for $5 \mathrm{~min}$, rising from $50{ }^{\circ} \mathrm{C}$ to $280^{\circ} \mathrm{C}$ at $5{ }^{\circ} \mathrm{C} / \mathrm{min}$, and then finally held isothermally at $280{ }^{\circ} \mathrm{C}$ for $15 \mathrm{~min}$. The injector temperature was $250{ }^{\circ} \mathrm{C}$; detector temperature $270{ }^{\circ} \mathrm{C}$; carrier gas helium $(0.9 \mathrm{~mL} / \mathrm{min})$; and split mode (split ratio, 1:20). The retention indices were calculated based on the retention times of the standard alkane series (C7-C40) purchased from Sigma-Aldrich (Sigma Aldrich GmbH, Sternheim, Germany). Enhanced ChemStation software, version MSD F.01.01.2317 (Agilent Technologies, Middelburg, The Netherlands), was used for recording and integrating the chromatograms. Quantitation was carried out based on the normalization method using the reading of three chromatographic runs. The compounds were identified by comparison of their mass spectral data and their retention indices (RIs) with those reported in the Wiley Registry of Mass Spectral Data (9th Ed.), NIST Mass Spectral Library (2011), and references [46,47].

\subsection{Biological Evaluation}

\subsubsection{Antibacterial Assay}

The antimicrobial activity was determined using two commonly known standard bacterial strains: Staphylococcus aureus (ATCC 25923) as an example of Gram-positive bacteria and Pseudomonas aeruginosa (ATCC 85327) as representative of Gram-negative microbes. The antibacterial activity of the essential oils was evaluated using modified agardisc diffusion and broth micro-dilution techniques (MIC) that were reported previously in details. Briefly, the suspensions of the utilized microorganisms were prepared to a final concentration of approximately $1 \times 10^{6} \mathrm{CFU} / \mathrm{mL}$, that followed by inoculating the Mueller Hinton agar (Biomerieux, Marcy l'Étoile, France) with the pathogens. Wells with a diameter of $6 \mathrm{~mm}$ were obtained and loaded with $100 \mu \mathrm{L}$ of $30 \mathrm{mg} / \mathrm{mL}$ of essential oil. DMSO, ampicillin $(10 \mu \mathrm{g} / \mathrm{mL})$, and gentamycin $(10 \mu \mathrm{g} / \mathrm{mL})$ were used as controls. The diameters of the growth inhibition zones were determined in triplicate after incubation at $37{ }^{\circ} \mathrm{C}$ for $24 \mathrm{~h}$. The MICs of the essential oils were determined by micro-dilution method where the oils were dissolved in 5\% DMSO and then were diluted with the broth in 96-well plates to obtain $(4-0.007 \mathrm{mg} / \mathrm{mL})$ concentrations. The adjusted bacterial suspension concentrations were then added and the plates were incubated at $37^{\circ} \mathrm{C}$ for $24 \mathrm{~h}$ (bacteria). The concentration in the first well showed no visible turbidity matching, with a negative control defined as the MIC. Each test was performed in triplicate [48].

\subsubsection{Antioxidant Assay}

The 2,2-diphenyl-1-picryl-hydrazyl-hydrate (DPPH), 2,2-azino-bis(3-ethylbenzothiazo line-6-sulphonic acid) (ABTS) radical scavenging, and ferric reducing power (FRAP) assays were adopted to determine the in vitro antioxidant activity of the essential oils. The methods were described with all details previously by the same team [49]. In the DPPH assay, the methanol solutions $(1 \mathrm{~mL})$ containing $1-500 \mu \mathrm{g} / \mathrm{mL}$ of the essential oils was 
mixed with $4 \mathrm{~mL}$ of a $0.004 \%$ methanol solution of DPPH, and the absorbance was measured at $517 \mathrm{~nm}$ after incubation in the dark for $30 \mathrm{~min}$ at room temperature, while in ABTS assay the diluted methanol essential oils solutions $(1 \mathrm{~mL})$ were mixed with freshly prepared ABTS solution $(2 \mathrm{~mL})$. The sample absorbance was read at $734 \mathrm{~nm}$ after a $30 \mathrm{~min}$ incubation at room temperature. However, in FRAP assay, sample solution $(0.1 \mathrm{~mL})$ was added to premixed FRAP reagent $(2 \mathrm{~mL}$ ) containing acetate buffer, 2,4,6-tris(2-pyridyl)-s-triazine in $\mathrm{HCl}$ and ferricchloride in a ratio of 10:1:1 $(v / v / v)$. Then, the absorbance was detected at $593 \mathrm{~nm}$ after a $30 \mathrm{~min}$ incubation at room temperature. Citric acid was used as a positive control [50].

\subsubsection{Cytotoxicity Assay}

The 3-(4,5-dimethylthiazol-2-yl)-2,5-diphenyltetrazolium bromide (MTT) assay was used to assess the cytotoxic activity of the essential oils obtained from E. allioides, E. polycarpa, F. clemaditifolia, H. intermedia, and the standard drug doxorubicin against two different cancer cells; HeLa and HepG-2. All the details are mentioned in previous work by the team. The cells $\left(2 \times 10^{4}\right.$ cells per well $)$ were seeded in 96-well plates, and incubated for $24 \mathrm{~h}$. The stock solution $(100 \mathrm{mg} / \mathrm{mL})$ of essential oils in DMSO was diluted with the media, and each sample was incubated with cells for $24 \mathrm{~h}$. The MTT solution $(0.5 \mathrm{mg} / \mathrm{mL})$ was added and incubated for $4 \mathrm{~h}$. The DMSO $(100 \mu \mathrm{L})$ was used to dissolve the formazan crystals. The absorbance was measured at $570 \mathrm{~nm}$. Experiments were performed in triplicate [40,51-53].

\subsection{Statistical Analysis}

Unless otherwise specified in the technique, all tests were repeated three times. Continuous variables were expressed as mean \pm SD. The IC50 value was defined as the concentration of the substance that resulted in a 50\% decrease or inhibition of biological activity. A one-way analysis of variance (ANOVA) was used to determine statistical significance, followed by a Tukey's post hoc test, with a significance level of $p<0.05$.

\subsection{Multivariate Analysis}

GC-MS data were subjected to multivariate analysis. Principal component analysis (PCA) is the first step in studying the data to offer an overview of all observations and samples to detect and analyse groups, trends, and significant outliers. Hierarchical cluster analysis (HCA) was then employed to enable sample clustering. The clustering patterns were built adopting the entire linkage approach used for group formation; this presentation is more efficient when the Euclidean approach calculates the distance between samples (points). A quantitative calibration model, partial least squares (PLS), was designed to develop a linear relationship between the GC-MS peak area $(X)$ matrix and antioxidant activity $(\mathrm{Y})$ matrix. In this situation, there was no partition of data into model and test set as just 12 samples were assessed (small data set). Therefore, predicting antioxidant activity for fresh samples was not our main concern. The root mean square error (RMSE) and correlation coefficient assessed the PLS-R model capability (R2). PCA, HCA, and PLS were accomplished using CAMO's Unscrambler ${ }^{\circledR}$ X 10.4 software (Computer-Aided Modeling, As, Norway).

\section{Conclusions}

In this study, the chemical profiles, antimicrobial, cytotoxic, and antioxidant activities of four essential oils obtained from the aerial parts of Elaeosticta allioides, Elaeosticta polycarpa, Hyalolaena intermedia, and Ferula clematidifolia were reported for the first time. Altogether, 100 components were identified in their volatile oils, in which the oxygenated monoterpenes and sesquiterpenes represent the major constituents. Multivariate analysis was adopted to correlate the studied species based on the chemical and biological data, revealing a close relation between Ferula and Elaeosticta. The partial least square regression model showed excellent prediction results for the antioxidant activity based on GC-MS metabolic profiling. 
In addition, Ferula showed superior biological activity in all experiments that might present a good source for many drug leads, especially for those diseases associated with the high level of oxidative stress. These products are widely accepted among the populations since most of these plants have been used for ages in culinary purposes as food. Therefore, it will be of great value if these plants are applied for therapeutic uses. However, more studies are required to ensure the efficacy and the safety of the drug before its approval.

Author Contributions: D.N.J. and D.K.A. collected the plant material and isolated the essential oils; H.A.G. identified the volatile compounds, conducted the chemometric analysis, and wrote the manuscript; K.S.T. sample collection and plants authentication; N.M.A.M. and M.L.A. supervised the study, and wrote and revised the whole manuscript; N.Z.M. performed the biological studies, supervised the study and writing of the manuscript. All authors have read and agreed to the published version of the manuscript.

Funding: This research was funded by King Saud University Researchers Supporting Project number (RSP-2021/294), King Saud University, Riyadh, Saudi Arabia.

Institutional Review Board Statement: Not applicable.

Informed Consent Statement: Not applicable.

Data Availability Statement: All the data are available via the corresponding authors upon request.

Acknowledgments: The authors would like to thank the King Saud University Researchers Supporting Project number (RSP-2021/294), King Saud University, Riyadh, Saudi Arabia.

Conflicts of Interest: The authors declare no conflict of interest.

\section{References}

1. Pimenov, M.G.; Tojibaev, K.; Kljuykov, E.V.; Degtjareva, G.V. Kuramosciadium (Umbelliferae): A new genus from the Uzbekistanian part of the Western Tian Shan mountains. Syst. Bot. 2011, 36, 487-494. [CrossRef]

2. Sennikov, A.N.; Tojibaev, K.S.; Khassanov, F.O.; Beshko, N.Y. The flora of Uzbekistan project. Phytotaxa 2016, 282, 107-118. [CrossRef]

3. Mamadalieva, N.Z.; Abdullaeva, N.S.; Rosenau, T.; Fakhrutdinova, M.; Azimova, S.S.; Bohmdorfer, S. Composition of essential oils from four Apiaceae and Asteraceae species growing in Uzbekistan. Nat. Prod. Res. 2018, 32, 1118-1122. [CrossRef] [PubMed]

4. Ali, B.; Al-Wabel, N.A.; Shams, S.; Ahamad, A.; Khan, S.A.; Anwar, F. Essential oils used in aromatherapy: A systemic review. Asian Pac. J. Trop. Biomed. 2015, 5, 601-611. [CrossRef]

5. Tojibaev, K.S.; Beshko, N.Y.; Turginov, O.T.; Lyskov, D.F.; Ukrainskaja, U.A.; Kljuykov, E.V. An annotated checklist of the endemic Apiaceae of Uzbekistan. Phytotaxa 2020, 455, 70-94. [CrossRef]

6. Khojimatov, O.K.; Abdiniyazova, G.J.; Pak, V.V. Some wild growing plants in traditional foods of Uzbekistan. J. Ethn. Foods 2015, 2, 25-28. [CrossRef]

7. Azimova, D.E.; Kubakova, K.; Abdshukurov, J.; Sharipova, M. The Apiaceae family is listed in the Red Book of the Republic of Uzbekistan types of Series. Int. J. Adv. Sci. Technol. 2020, 29, 3522-3525.

8. Lyskov, D.; Kljuykov, E.; Ukrainskaja, U.; Tojibaev, K. Notes on the genus Hyalolaena (Apiaceae) with description of a new species H. zhang-minglii from Xinjiang, western China. Phytotaxa 2019, 388, 10. [CrossRef]

9. Klyuykov, E.V.; Pimenov, M.G.; Tikhomirov, V.N. Elaeosticta Fenzl, a genus of the family Umbelliferae, independent with respect to Scaligeria DC. Bull. Mosc. Soc. Nat. 1976, 8, 83-94.

10. Pimenov, M.G.; Skljar, J.E. Plant Resources of the USSR: Flowering Plants, Their Chemical Composition, Use; Families RutaceaeElaeagnaceae; Nauka Publishing: Moscow, Russia, 1988.

11. Sağıroğlu, M.; Duman, H. Ferula brevipedicellata and F. duranii (Apiaceae), two new species from Anatolia, Turkey. Ann. Bot. Fenn. 2010, 47, 293-300. [CrossRef]

12. Rakhimova, N. Ontogenesis of Ferula kyzylkumica Korovin (Apiaceae) the relict mountains of Eastern Kyzylkum (Uzbekistan). Int. J. Sci. Res. 2016, 5, 25-29.

13. Duman, H.; Sağıroğlu, M. A new species of Ferula (Apiaceae) from South Anatolia, Turkey. Bot. J. Linn. Soc. 2005, 147, 357-361. [CrossRef]

14. Sonigra, P.; Meena, M. Metabolic profile, bioactivities, and variations in the chemical constituents of essential oils of the Ferula genus (Apiaceae). Front. Pharmacol. 2020, 11, 608649. [CrossRef]

15. Alyousif, M.S.; Al-Abodi, H.R.; Almohammed, H.; Alanazi, A.D.; Mahmoudvand, H.; Shalamzari, M.H.; Salimikia, I. Chemical composition, apoptotic activity, and antiparasitic effects of Ferula macrecolea essential oil against Echinococcus granulosus protoscoleces. Molecules 2021, 26, 888. [CrossRef]

16. Najaf Najafi, M.; Arianmehr, A.; Sani, A.M. Preparation of Barije (Ferula gummosa) essential oil-loaded liposomes and evaluation of physical and antibacterial effect on Escherichia coli O157:H7. J. Food Prot. 2020, 83, 511-517. [CrossRef] [PubMed] 
17. Znati, M.; Filali, I.; Jabrane, A.; Casanova, J.; Bouajila, J.; Ben Jannet, H. Chemical composition and in vitro evaluation of antimicrobial, antioxidant and antigerminative properties of the seed oil from the Tunisian endemic Ferula tunetana Pomel ex Batt. Chem. Biodivers. 2017, 14, e1600116. [CrossRef] [PubMed]

18. Elghwaji, W.; El-Sayed, A.M.; El-Deeb, K.S.; ElSayed, A.M. Chemical composition, antimicrobial and antitumor potentiality of essential oil of Ferula tingitana L. Apiaceae grow in Libya. Pharmacogn. Mag. 2017, 13, S446-S451. [CrossRef] [PubMed]

19. Youssef, F.S.; Mamatkhanova, M.A.; Mamadalieva, N.Z.; Zengin, G.; Aripova, S.F.; Alshammari, E.; Ashour, M.L. Chemical profiling and discrimination of essential oils from six Ferula species using GC analyses coupled with chemometrics and evaluation of their antioxidant and enzyme inhibitory potential. Antibiotics 2020, 9, 518. [CrossRef] [PubMed]

20. Barra, A. Factors affecting chemical variability of essential oils: A review of recent developments. Nat. Prod. Commun. 2009, 4, 1147-1154. [CrossRef] [PubMed]

21. Hamedi, A.; Lashgari, A.P.; Pasdaran, A. Antimicrobial activity and analysis of the essential oils of selected endemic edible Apiaceae plants root from Caspian Hyrcanian region (North of Iran). Pharm. Sci. 2019, 25, 138-144. [CrossRef]

22. Gad, H.; Al-Sayed, E.; Ayoub, I. Phytochemical discrimination of Pinus species based on GC-MS and ATR-IR analyses and their impact on Helicobacter pylori. Phytochem. Anal. 2021. [CrossRef]

23. Gad, H.A.; Mamadalieva, N.Z.; Böhmdorfer, S.; Rosenau, T.; Zengin, G.; Mamadalieva, R.Z.; Al Musayeib, N.M.; Ashour, M.L. GC-MS based identification of the Volatile Components of Six Astragalus Species from Uzbekistan and Their Biological Activity. Plants 2021, 10, 124. [CrossRef]

24. Plunkett, G.M.; Pimenov, M.G.; Reduron, J.-P.; Kljuykov, E.V.; van Wyk, B.-E.; Ostroumova, T.A.; Henwood, M.J.; Tilney, P.M.; Spalik, K.; Watson, M.F.; et al. Apiaceae. In Flowering Plants. Eudicots: Apiales, Gentianales (except Rubiaceae); Kadereit, J.W., Bittrich, V., Eds.; Springer International Publishing: Berlin/Heidelberg, Germany, 2018; pp. 9-206. [CrossRef]

25. Dastan, D.; Hamah-Ameen, B.A.; Salehi, P.; Ghaderi, H.; Miran, M. Chemical composition and bioactivities of essential oils from different plant parts of Ferula pseudalliacea Rech.f. as an endemic plant from Iran. Nat. Prod. Res. 2021, 1-6. [CrossRef]

26. Alipour, Z.; Taheri, P.; Samadi, N. Chemical composition and antibacterial activity of the essential oils from flower, leaf and stem of Ferula cupularis growing wild in Iran. Pharm. Biol. 2015, 53, 483-487. [CrossRef]

27. Eftekhar, F.; Yousefzadi, M.; Borhani, K. Antibacterial activity of the essential oil from Ferula gummosa seed. Fitoterapia 2004, 75, 758-759. [CrossRef] [PubMed]

28. Wink, M. Evolutionary advantage and molecular modes of action of multi-component mixtures used in phytomedicine. Curr. Drug Metab. 2008, 9, 996-1009. [CrossRef] [PubMed]

29. Guo, F.; Liang, Q.; Zhang, M.; Chen, W.; Chen, H.; Yun, Y.; Zhong, Q.; Chen, W. Antibacterial activity and mechanism of linalool against Shewanella putrefaciens. Molecules 2021, 26, 245. [CrossRef] [PubMed]

30. Liu, X.; Cai, J.; Chen, H.; Zhong, Q.; Hou, Y.; Chen, W.; Chen, W. Antibacterial activity and mechanism of linalool against Pseudomonas aeruginosa. Microb. Pathog. 2020, 141, 103980. [CrossRef]

31. Li, L.; Shi, C.; Yin, Z.; Jia, R.; Peng, L.; Kang, S.; Li, Z. Antibacterial activity of alpha-terpineol may induce morphostructural alterations in Escherichia coli. Braz. J. Microbiol. 2014, 45, 1409-1413. [CrossRef]

32. Silva Pereira, R.L.; Campina, F.F.; Costa, M.D.S.; Pereira da Cruz, R.; Sampaio de Freitas, T.; Lucas Dos Santos, A.T.; Cruz, B.G.; Maciel de Sena Junior, D.; Campos Lima, I.K.; Xavier, M.R.; et al. Antibacterial and modulatory activities of beta-cyclodextrin complexed with (+)-beta-citronellol against multidrug-resistant strains. Microb. Pathog. 2021, 156, 104928. [CrossRef] [PubMed]

33. Candelaria-Duenas, S.; Serrano-Parrales, R.; Avila-Romero, M.; Meraz-Martinez, S.; Orozco-Martinez, J.; Avila-Acevedo, J.G.; Garcia-Bores, A.M.; Cespedes-Acuna, C.L.; Penalosa-Castro, I.; Hernandez-Delgado, T. Evaluation of the antimicrobial activity of some components of the essential oils of plants used in the traditional medicine of the Tehuacan-Cuicatlan valley, Puebla, Mexico. Antibiotics 2021, 10, 295. [CrossRef] [PubMed]

34. Munteanu, I.G.; Apetrei, C. Analytical methods used in determining antioxidant activity: A Review. Int. J. Mol. Sci. 2021, 22, 3380. [CrossRef]

35. Amiri, H. Chemical composition and antioxidant activity of essential oil and methanolic extracts of Ferula microcolea (Boiss.) Boiss (Apiaceae). Int. J. Food Prop. 2014, 17, 722-730. [CrossRef]

36. Nguir, A.; Mabrouk, H.; Douki, W.; Ismail, M.B.; Jannet, H.B.; Flamini, G. Chemical composition and bioactivities of the essential oil from different organs of Ferula communis L. growing in Tunisia. Med. Chem. Res. 2016, 25, 515-525. [CrossRef]

37. Kavoosi, G.; Rowshan, V. Chemical composition, antioxidant and antimicrobial activities of essential oil obtained from Ferula assa-foetida oleo-gum-resin: Effect of collection time. Food Chem. 2013, 138, 2180-2187. [CrossRef] [PubMed]

38. Adorjan, B.; Buchbauer, G. Biological properties of essential oils: An updated review. Flavour Fragr. J. 2010, 25, 407-426. [CrossRef]

39. Bakkali, F.; Averbeck, S.; Averbeck, D.; Idaomar, M. Biological effects of essential oils-A review. Food Chem. Toxicol. 2008, 46, 446-475. [CrossRef]

40. Sobeh, M.; Mamadalieva, N.Z.; Mohamed, T.; Krstin, S.; Youssef, F.S.; Ashour, M.L.; Azimova, S.S.; Wink, M. Chemical profiling of Phlomis thapsoides (Lamiaceae) and in vitro testing of its biological activities. Med. Chem. Res. 2016, 25, 2304-2315. [CrossRef]

41. Khadir, A.; Sobeh, M.; Gad, H.A.; Benbelaid, F.; Bendahou, M.; Peixoto, H.; Sporer, F.; Ashour, M.L.; Wink, M. Chemical composition and biological activity of the essential oil from Thymus lanceolatus. Z. Fur Nat. C 2016, 71, 155-163. [CrossRef] [PubMed]

42. Hamdan, D.; Ashour, M.L.; Mulyaningsih, S.; El-Shazly, A.; Wink, M. Chemical composition of the essential oils of variegated pink-fleshed lemon (Citrus $x$ limon L. Burm. f.) and their anti-inflammatory and antimicrobial activities. Z. Fur Nat. C 2013, 68, 275-284. 
43. El-Ahmady, S.H.; Ashour, M.L.; Wink, M. Chemical composition and anti-inflammatory activity of the essential oils of Psidium guajava fruits and leaves. J. Essent. Oil Res. 2013, 25, 475-481. [CrossRef]

44. Wink, M.; Ashour, M.L.; El-Readi, M.Z. Secondary metabolites from plants inhibiting ABC transporters and reversing resistance of cancer cells and microbes to cytotoxic and antimicrobial agents. Front. Microbiol. 2012, 3, 130. [CrossRef]

45. Li, K.; Zhou, R.; Wang Jia, W.; Li, Z.; Li, J.; Zhang, P.; Xiao, T. Zanthoxylum bungeanum essential oil induces apoptosis of HaCaT human keratinocytes. J. Ethnopharmacol. 2016, 186, 351-361. [CrossRef]

46. Adams, R.P. Identification of Essential Oil Components by Gas Chromatography/Quadrupole Mass Spectroscopy, 3rd ed.; Allured Pub Corp.: Carol Stream, IL, USA, 2007.

47. Babushok, V.I.; Linstrom, P.J.; Zenkevich, I.G. Retention indices for frequently reported compounds of plant essential oils. J. Phys. Chem. Ref. Data 2011, 40, 043101. [CrossRef]

48. Mamadalieva, N.Z.; Herrmann, F.; El-Readi, M.Z.; Tahrani, A.; Hamoud, R.; Egamberdieva, D.R.; Azimova, S.S.; Wink, M. Flavonoids in Scutellaria immaculata and S. ramosissima (Lamiaceae) and their biological activity. J. Pharm. Pharmacol. 2011, 63, 1346-1357. [CrossRef]

49. Mamadalieva, N.Z.; Youssef, F.S.; Ashour, M.L.; Sasmakov, S.A.; Tiezzi, A.; Azimova, S.S. Chemical composition, antimicrobial and antioxidant activities of the essential oils of three Uzbek Lamiaceae species. Nat. Prod. Res. 2019, 33, 2394-2397. [CrossRef]

50. Zengin, G.; Uysal, S.; Ceylan, R.; Aktumsek, A. Phenolic constituent, antioxidative and tyrosinase inhibitory activity of Ornithogalum narbonense L. from Turkey: A phytochemical study. Ind. Crop. Prod. 2015, 70, 1-6. [CrossRef]

51. Mamadalieva, N.Z.; Ovidi, E.; Vinciguerra, V.; Ashour, M.L.; Azimova, S.S.; Tiezzi, A. Chemical constituents of Thymus seravschanicus and their biological activity. Chem. Nat. Compd. 2016, 52, 352-355. [CrossRef]

52. El-Readi, M.Z.; Eid, H.H.; Ashour, M.L.; Eid, S.Y.; Labib, R.M.; Sporer, F.; Wink, M. Variations of the chemical composition and bioactivity of essential oils from leaves and stems of Liquidambar styraciflua (Altingiaceae). J. Pharm. Pharmacol. 2013, 65, 1653-1663. [CrossRef]

53. Mulyaningsih, S.; Youns, M.; El-Readi, M.Z.; Ashour, M.L.; Nibret, E.; Sporer, F.; Herrmann, F.; Reichling, J.; Wink, M. Biological activity of the essential oil of Kadsura longipedunculata (Schisandraceae) and its major components. J. Pharm. Pharmacol. 2010, 62, 1037-1044. [CrossRef] [PubMed] 